\title{
GREENHOUSE AND FIELD GROWTH OF NORTHERN RED OAK SEEDLINGS INSIDE DIFFERENT TYPES OF TREESHELTERS
}

\author{
by William E. Sharpe, Bryan R. Swistock, Kelly A. Mecum, and Michael C. Demchik
}

\begin{abstract}
Greenhouse and field experiments were used to measure growth and survival of northern red oak seedlings (Quercus rubra L.) inside brown translucent, clear acrylic, and woven wire treeshelters compared to the growth and survival of unsheltered seedlings. In the greenhouse, seedlings grown in brown plastic and clear acrylic shelters had significantly reduced stem, leaf, and root development compared to unsheltered seedlings. Seedlings in clear shelters grew taller than control seedlings, but none were self-supporting after removal of the shelters. Reduced growth in the brown shelters was attributed to an $80 \%$ reduction in photosynthetically active radiation (PAR). In the field study, 2-year-old red oak seedlings grown in brown and clear shelters experienced lower mortality (55\% and $40 \%$, respectively) than unsheltered seedlings (60\%), but most were unable to support themselves after removal of the shelters because of increased height growth and inadequate stem development. Half of the seedlings inside clear shelters experienced dieback of new growth during an unusually warm early growing season. Seedlings in the wire shelters were not supported or protected from mechanical stress (wind) and they were exposed to ambient temperatures. Wire-shelter seedlings had the lowest mortality (20\%) and were self-supporting but significantly shorter than seedlings in the clear and brown shelters. Wire shelters show promise as an alternative to solid plastic shelters for producing self-supporting seedlings with comparable growth and greater survival at a similar overall cost.
\end{abstract}

Key Words. Photosynthetically active radiation; maximum temperatures; mechanical stress; survival.

Treeshelters were first developed nearly 2 decades ago in Great Britain to protect planted tree seedlings from animal browsing. Early studies suggested shelters increased seedling survival and promoted increased height growth by creating a more favorable microenvironment (Tuley 1985; Potter 1988, 1991; Burger et al. 1992). Sheltered seedlings also have increased leaf areas and reduced transpiration rates compared to unsheltered trees (Burger et al. 1992;
Kjelgren 1994). These reported growth and survival benefits from shelters have earned them acceptance in the regeneration of northern red oak (Quercus rubra L.) and other tree species.

Other research, however, suggests the effects of brown plastic treeshelters on tree seedling growth and development may not be entirely beneficial. Although taller seedlings are produced, they typically have reduced stem caliper (Tuley 1981; Lantagne et al. 1990; Smith 1993; Kjelgren 1994; Burger et al. 1996) and smaller root systems that may not support the seedling when the shelter is removed (Potter 1991; Mayhead and Jenkins 1992; Burger et al. 1992; Mayhead and Boothman 1997). Temperature regimes inside shelters have also been reported to be outside optimal ranges for growth of some tree species (Kozlowski 1979; Mebrahtu and Hanover 1991; Kjelgren 1994; Kjelgren and Rupp 1997; Swistock et al. 1999).

The observed positive and negative growth changes in sheltered trees are consistent with expected physiological responses to environmental conditions inside shelters. The greenhouse-like environment in shelters could increase height growth by increasing temperature and humidity and decreasing transpiration (Tuley 1985; Burger et al. 1992). Decreased stem and root development and greater leaf area noted in sheltered seedlings are consistent with shade acclimation and light reduction responses in trees (Bjorkman 1981; Pierson et al. 1990; Kjelgren 1994). These same growth characteristics also can be explained by the structural support, wind protection and reduction in mechanical stress provided by the shelter (Harris et al. 1976; Jaffe and Forbes 1993). The protection provided by the shelter allows the tree to allocate more resources to stem elongation and leaf production and less to support structures such as stem diameter and root mass.

As use of treeshelters increases, additional research is needed to determine their impact on seedling development and to investigate alternative treeshelter de- 
signs. The objective of this study was to compare the growth characteristics of northern red oak seedlings grown in different types of treeshelters in a controlled greenhouse environment and an open area formerly occupied by a stand of mature red oak trees.

\section{EXPERIMENTAL DESIGN AND METHODS Greenhouse Experiment}

A greenhouse study was conducted to determine the effects of 2 types of treeshelters on red oak seedlings grown under controlled conditions. On May 10 , 1994, 60 pre-germinated northern red oak acorns from the same mother tree located in State College, Pennsylvania, were planted in $0.03-\mathrm{m}^{3}$ pots filled with a mixture consisting of $70 \%$ ProMix $^{\mathrm{TM}}$ and $30 \%$ mineral soil. The 60 pots were placed on raised benches under a natural photoperiod and were divided into a randomized block design with 4 blocks, 3 treatments, and 5 replications per treatment. The 3 treatments consisted of brown plastic Tubex ${ }^{\circledR}$ shelters, clear extruded acrylic shelters, and a control with no treeshelters. Wire shelters were not tested in the greenhouse. The shelters were $10 \mathrm{~cm}$ (4 in.) in diameter and $1.5 \mathrm{~m}(5 \mathrm{ft})$ tall and were anchored to wooden stakes in the pots immediately after the acorns were planted. Each pot received $450 \mathrm{~mL}$ of deionized water twice per week.

Ambient air temperatures inside the greenhouse were recorded with a thermograph and ranged between $9^{\circ} \mathrm{C}$ and $32^{\circ} \mathrm{C}\left(48^{\circ} \mathrm{F}\right.$ and $\left.90^{\circ} \mathrm{F}\right)$ during the experiment. An automated greenhouse cooling system prevented ambient temperatures from exceeding $32^{\circ} \mathrm{C}$. Temperatures inside individual shelters were not measured during the experiment. The seedlings were allowed to grow for 102 days while weekly measurements of height growth and stem diameter were made. At the conclusion of the study, the seedlings were sacrificed so that height growth, stem diameter and dry weight, leaf area and dry weight, and root dry weight could be measured. Mean seedling growth parameters were compared statistically between treatments using Duncan's Multiple Range Test at $\alpha=0.05$.

Measurements of photosynthetically active radiation (PAR) were made both outside and inside the greenhouse and inside both types of treeshelters to determine how the greenhouse glass and the treeshelter plastic may reduce PAR available to seedlings grown in the shelters. PAR was measured with a Li-Cor LI-190SZ light sensor connected to a voltmeter. Millivolts from

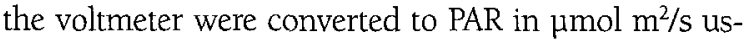
ing an empirical equation developed by comparing millivolt measurements from the light sensor to a calibrated light sensor attached to a portable photosynthesis instrument (LI 6200; LiCor, Lincoln, NE). Measurements were made at 2 heights $(18.3 \mathrm{~cm}$ [7.2 in.] and $44.5 \mathrm{~cm}$ [17.5 in.]) within 3 brown plastic shelters and 3 clear acrylic shelters at 3 times during a clear September day. Ambient PAR levels were measured prior to each shelter measurement. Measurements were limited to 1 day because we presumed PAR reductions would be relatively constant and related to the light transmissivity of the shelter materials.

\section{Field Experiment}

In May 1995, 80 2-year-old (2-0 bare-root stock) northern red oak seedlings were weighed, measured, and planted in a plot within an open area in southwestern Pennsylvania that had been clear cut to remove a red oak stand. The study plot was cleared to bare ground by hand prior to planting to eliminate competing vegetation and limed and fertilized at the time of planting to ameliorate acidic soil conditions. The plot received $6,600 \mathrm{~kg} / \mathrm{ha}$ of dolomitic lime $\left(53.5 \% \mathrm{CaCO}_{3}, 42 \% \mathrm{MgCO}_{3}\right), 110 \mathrm{~kg} / \mathrm{ha} \mathrm{K}_{2} \mathrm{O}$, and $220 \mathrm{~kg} / \mathrm{ha}$ of $\mathrm{P}_{2} \mathrm{O}_{5}$. These lime and fertilizer rates were adapted from soil fertility work conducted by Demchik (1998) in an area adjacent to the study plot.

The 80 seedlings were randomly divided into 4 treatments with 20 seedlings in each treatment. The 4 treatments included brown translucent Tubex shel-

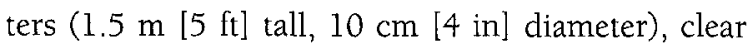
acrylic shelters $(1.5 \mathrm{~m}$ tall, $10 \mathrm{~cm}$ diameter), wire mesh shelters $(1.3 \mathrm{~cm}$ plastic-coated welded wire

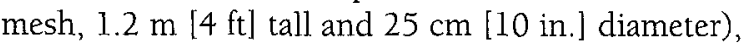
and unsheltered controls. The seedlings did not receive any supplemental irrigation during the experiment. Precipitation was not measured on the field plot but was available from a state acidic deposition monitoring network site at Laurel Hill State Park approximately $12.8 \mathrm{~km}(7.9 \mathrm{mi})$ southwest of the plot (Lynch et al. 1996, 1997, 1998).

Seedling height and survival were measured annually during midsummer (July or August) for 3 
years after planting. Competing vegetation on the study plot was removed by hand as needed during each measurement period. Stem diameter was measured at the base of the seedling at the end of the experiment using a digital caliper. Mean seedling heights were statistically compared among the 4 treatments using the Tukey Multiple Means Comparison technique at $\alpha=0.05$.

Maximum temperatures inside shelters were measured on 2 days in 1995 using a Taylor maximum-minimum thermometer (Model 5458) wrapped in aluminum foil and suspended by monofilament fishing line. Four shelters of each type were randomly chosen and equipped with a thermometer. Maximum temperatures inside the open wire shelters were assumed to be equivalent to the ambient maximum temperatures. Photosynthetically active radiation was measured at 4 different times on 1 day (May 28, 1998) using a LI-190SA Quantum Sensor and similar protocols to those mentioned

previously. PAR was measured inside each type of shelter and outside the shelters on the plot.

\section{RESULTS AND DISCUSSION Greenhouse Study}

During the 102-day greenhouse experiment, no red oak seedling mortality occurred in any of the treatments. Statistically significant differences $(P \leq 0.05)$ in most growth parameters existed between seedlings grown in brown shelters, clear shelters, and unsheltered control seedlings (Figure 1). Clear shelters produced the tallest seedlings but compared to unsheltered seedlings they had smaller stem diameter and mass, smaller leaves, and smaller root systems. Seedlings grown inside brown shelters were smaller than unsheltered or clear sheltered seedlings in all stem, leaf, and root measures (Figure 1).

Seedlings from the clear shelters were unable to support their above-ground mass and bent to the ground after removal of the shelters. They also produced chlorotic leaves with numerous broken leaf

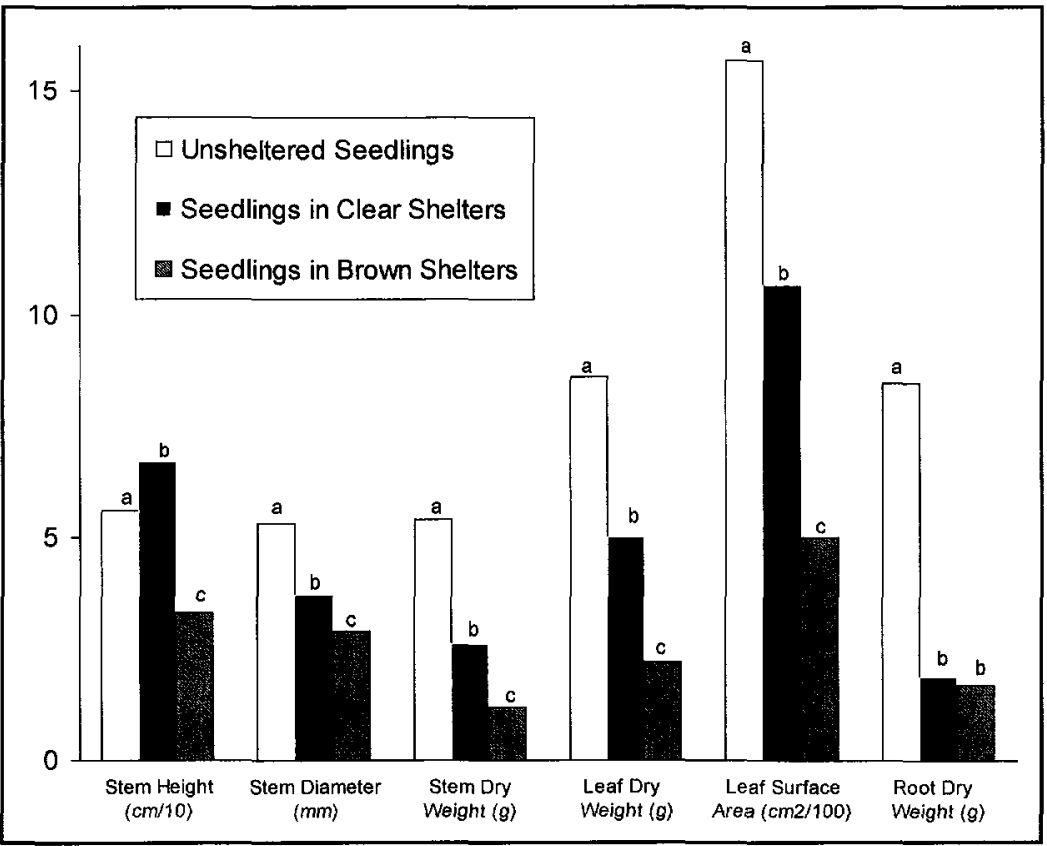

Figure 1. Mean stem, leaf, and root growth parameters for northern red oak seedlings grown for 102 days in brown plastic shelters, clear acrylic shelters, and outside shelters (control) in the greenhouse. Different letters above bars indicate means that are statistically different $(P \leq 0.05)$ using Duncan's Multiple Range Test. Note that stem height and leaf surface area were divided by constants (10 and 100, respectively) to allow them to be plotted on the same scale. midveins. Seedlings from the brown shelters were able to stand upright after removal of the shelters but also displayed chlorotic and broken leaves. Broken leaf midveins were evident on many of the mature leaves and occurred because the leaves had limited growing space inside the shelters before encountering the shelter wall. The cause of the foliar chlorosis was not determined, but chemical analysis of soil and foliage did not indicate an elementdeficiency cause.

The increased height growth and reduced stem, leaf, and root mass in clear sheltered seedlings are consistent with growth responses that result from added structural support and protection offered by the shelter (Harris et al. 1976; Jaffe and Forbes 1993). The unsheltered seedlings were shorter and sturdier with significantly larger root anchoring systems in response to the 
lack of support and exposure to wind stress generated by the greenhouse fans.

Differing light levels provide a possible explanation for observed growth differences between seedlings grown inside and outside brown shelters (Bjorkman 1981). In the greenhouse experiment, combined shading provided by the greenhouse and brown shelters could have been responsible for the reduced growth of red oak seedlings in the brown shelters. Photosynthetically active radiation (PAR) inside the greenhouse was reduced to $40 \%$ of ambient outdoor levels by the opaque greenhouse glass (Figure 2). The resulting PAR levels in brown shelters measured in September were only $20 \%$ of outdoor ambient, while clear shelters were reduced less drastically to $38 \%$ of outdoor levels. The decreased growth of red oak seedlings in shaded brown shelters agrees with past studies that showed reduced growth of northern red oak seedlings under reduced light conditions (Loach 1967, 1970; Kolb et al. 1990).

\section{Field Study}

Overall mortality of red oak seedlings among all of the treatments was $44 \%$ during the 3 -year field study. The highest mortality occurred among unsheltered control seedlings, with $45 \%$ dead after the first 3 months and $60 \%$ dead by the end of the third year. All of the living control seedlings were heavily browsed by white-tailed deer. Mortality also was high in the brown and clear shelters, with $55 \%$ and $40 \%$ of seedlings dead after 3 years, respectively. Nearly all of this mortality occurred in the first 3 months after planting. The lowest mortality occurred in the wire shelters where only $20 \%$ of the seedlings died after 3 years.

Precipitation records from Laurel Hill State Park indicate that precipitation was within $25 \%$ of normal for 14 of the 15 growing season months (May through September) during the study. The only exception occurred during September 1995 (the first grow- ing season), when precipitation was only about half of normal. Precipitation during the first 3 months of the study, when much of the seedling mortality occurred, was approximately $18 \%$ above normal.

In addition to having the highest mortality, unsheltered seedlings were consistently the shortest among the 4 treatments (Figure 3). The high mortality and low or even negative growth among unsheltered seedlings was attributed to browsing by white-tailed deer. By the end of the study period, all of the living unsheltered seedlings had evidence of severe browsing. Fifteen months after planting, seedlings in clear and brown shelters were significantly taller than seedlings in wire shelters or no shelters (Figure 3). Seedling height growth between clear and brown shelters was not significantly different. Reduced seedling growth in the clear shelters during June 1998 was the result of severe dieback of new growth in $50 \%$ of the clear shelters. This dieback did not affect seedlings in the other treatments. Seedlings in wire shelters were significantly taller than control seedlings but shorter than seedlings in clear or brown shelters (Figure 3).

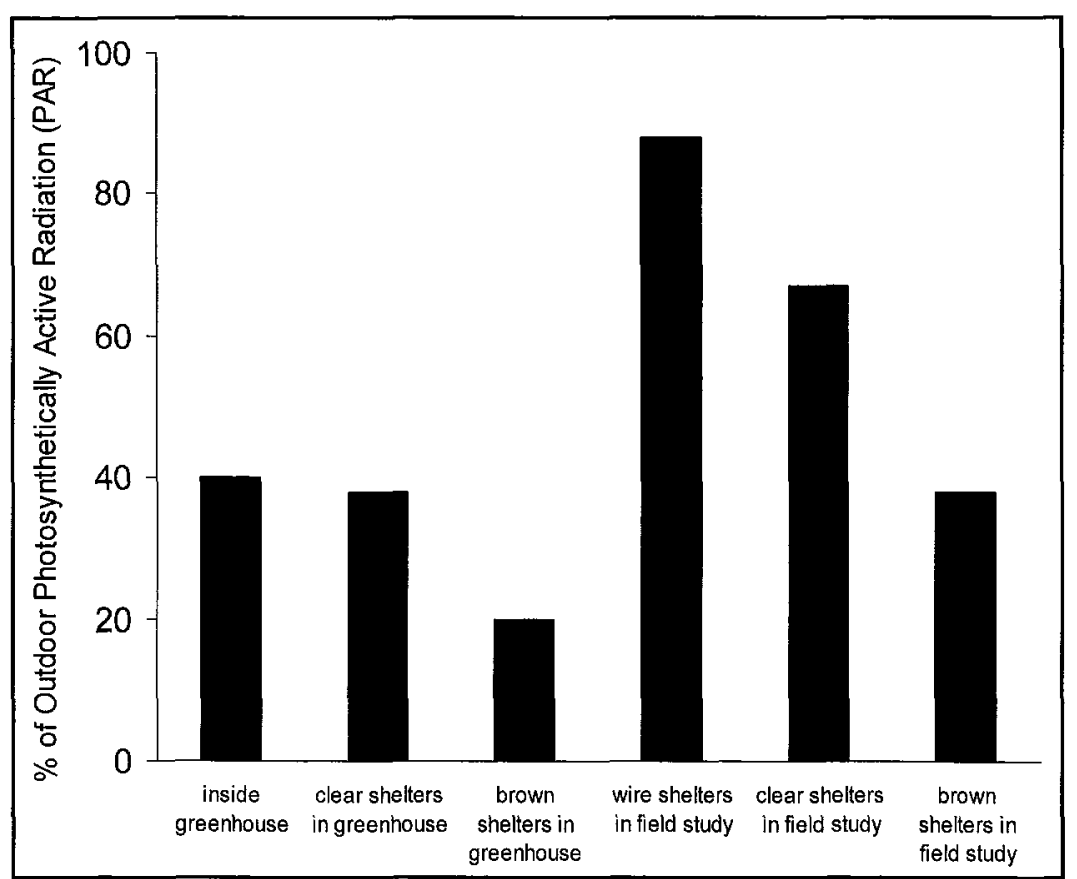

Figure 2. Mean percentage of ambient outdoor photosynthetically active radiation (PAR) measured inside the greenhouse and inside each of the treeshelter types both inside the greenhouse and in the field study. 


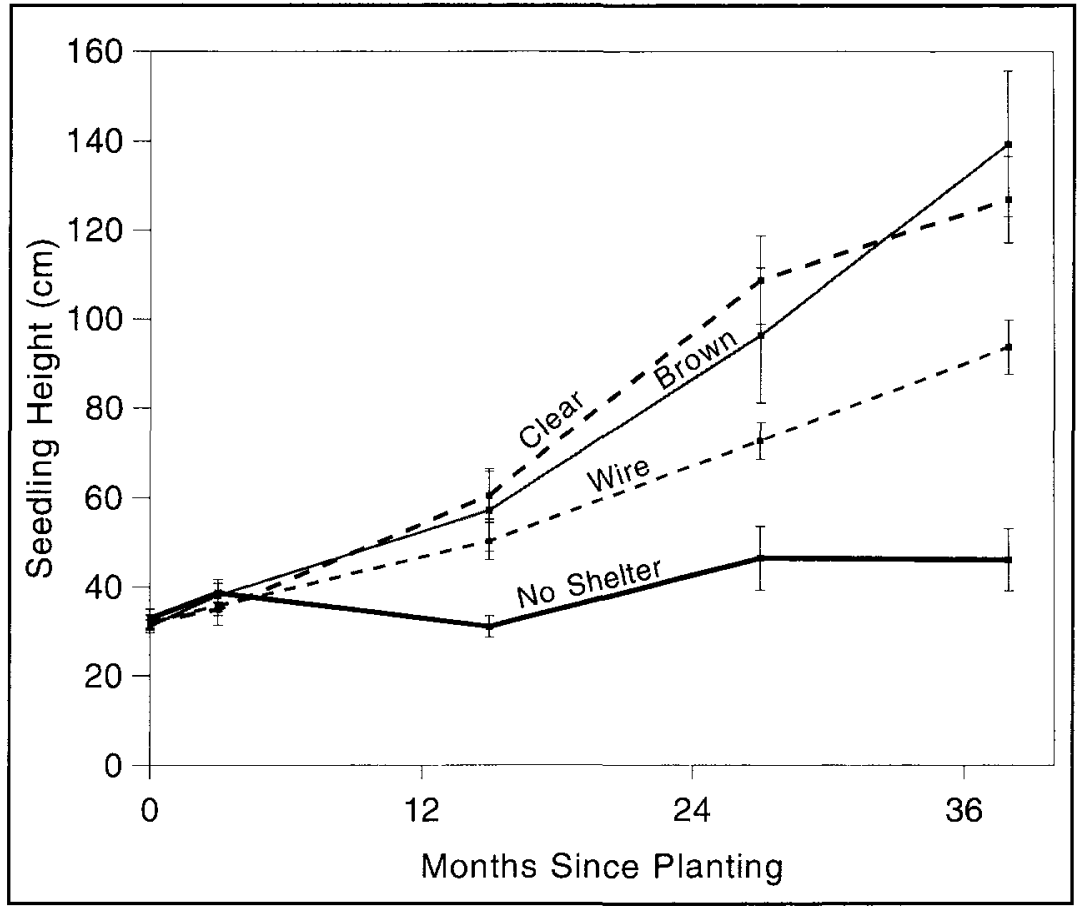

Figure 3. Mean northern red oak seedling stem height ( \pm 1 standard error) among the 4 treatments in the field during the 37-month study period starting in May 1995.

Measurements of stem diameter were made at the end of the experiment. Stem diameters were greatest for seedlings grown inside wire shelters and lowest for seedlings inside brown shelters and for unsheltered seedlings (Table 1). The ratio of stem diameter to stem height was used as an index to characterize the structural support provided by the seedlings and was compared to observations of seedling support made at the end of the study. Unsheltered and wire sheltered seedlings had the highest diameter-to-height ratios (shorter, sturdier seedlings) and, as a result, all of the seedlings in these treatments were able to stand upright without shelter support. Clear and brown sheltered seedlings had lower diameter-to-height ratios (taller, thinner seedlings), and nearly all of the seedlings in these 2 treatments bent to the ground after removal of the shelter. Our results indicate a stem diameter $(\mathrm{mm})$ to height $(\mathrm{cm})$ ratio of approximately 0.1 is necessary to provide structural support for red oak seedlings.

Photosynthetically active radiation (PAR) varied considerably among the different types of treeshelters in the field (Figure 2). PAR levels inside the wire, clear, and brown shelters were $88 \%, 67 \%$, and $38 \%$ compared to ambient outdoor PAR levels. These percentages were consistent between the 3 PAR measurement times. Linear regression analysis, based on the 27 measurements for each shelter type, further supported a consistent linear relationship between ambient and shelter PAR levels with $\mathrm{R}^{2}$ values of $0.74,0.96$ and 0.95 for the brown, clear, and wire shelters, respectively.

Our measurements of PAR inside brown treeshelters (38\%) is below the $50 \%$ shortwave radiation reduction reported by Kjelgren et al. (1997) and Burger et al. (1996) but above the $25 \%$ reported by Kjelgren (1994) for similar shelters. Light was probably not limiting seedling growth inside any of the shelter types in the field because oaks are most photosynthetically efficient at around 30\% full light (Phares 1971). The similarity in height and stem diameter growth between brown and clear sheltered seedlings in the field also suggested that shade acclimation was not a major cause of the observed growth patterns of seedlings in these shelter types. The results from the field and greenhouse suggested that PAR levels inside clear and brown treeshelters will not be limiting to red oak growth except in shaded sites where ambient outdoor PAR levels are already less than $50 \%$ of full sunlight and shelters further reduce PAR below critical levels.

Maximum daily temperatures inside the brown and clear shelters averaged $8.2^{\circ} \mathrm{C}$ and $11.7^{\circ} \mathrm{C}$ $\left(14.8^{\circ} \mathrm{F}\right.$ and $\left.21.1^{\circ} \mathrm{F}\right)$ warmer, respectively, than ambient levels during the 2 measurement days. Maximum temperatures inside individual brown and clear shelters exceeded $49^{\circ} \mathrm{C}\left(120^{\circ} \mathrm{F}\right)$ in some cases. Swistock et al. (1999) reported summer maximum temperatures inside brown treeshelters in Pennsylvania as high as $52^{\circ} \mathrm{C}\left(125.5^{\circ} \mathrm{F}\right)$, and other recent research has indicated that temperature regimes inside 
Table 1. Red oak stem height, stem diameter, and seedling support measurements for each of the 4 treatments made at the end of the 3-year field study.

\begin{tabular}{lllll}
\hline & $\begin{array}{l}\text { Unsheltered } \\
\text { seedlings }\end{array}$ & $\begin{array}{l}\text { Seedlings } \\
\text { inside } \\
\text { wire shelters }\end{array}$ & $\begin{array}{l}\text { Seedlings } \\
\text { inside } \\
\text { clear shelters }\end{array}$ & $\begin{array}{l}\text { Seedlings } \\
\text { inside } \\
\text { brown shelters }\end{array}$ \\
\hline $\begin{array}{l}\text { Measurement } \\
\quad \pm \text { std error (cm) }\end{array}$ & $46.13 \pm 7.0$ & $93.75 \pm 6.12$ & $126.92 \pm 9.73$ & $139.44 \pm 16.33$ \\
$\begin{array}{l}\text { Mean seedling stem diameter } \\
\quad \pm \text { std error (mm) }\end{array}$ \\
$\begin{array}{l}\text { Mean ratio of stem diameter (mm) } \\
\text { to stem height (cm) }\end{array}$ \\
$\begin{array}{l}\text { Percentage of seedlings able to } \\
\text { support themselves after shelter } \\
\text { removal }\end{array}$ & 0.197 & $12.25 \pm 0.72$ & $11.09 \pm 0.75$ & $9.04 \pm 0.68$ \\
\hline
\end{tabular}

plastic treeshelters may reach supraoptimal levels for seedling growth (Kjelgren 1994; Kjelgren and Rupp 1997). Very little is known about the effects of high temperature on growth of red oak, and the positiveversus-negative effects of increased temperatures inside the shelters could not be easily discerned from the limited temperature data collected in this study. The difference in growth between the plastic (clear and brown) shelters and the wire shelters represented the combined positive effects of increased temperatures and mechanical support provided by the shelter. Seedlings in wire shelters received little or no support from the $25-\mathrm{cm}$ (10-in.) diameter shelters and were exposed to wind stress. They responded with lower height growth than seedlings in brown or clear shelters (about 30 to $40 \mathrm{~cm}[12$ to 16 in.] less, Figure 3), but they were sturdier and had greater branching.

\section{CONCLUSIONS AND RECOMMENDATIONS}

As long as white-tailed deer exist in excessive numbers in the Northeast, treeshelters will probably have a role in regeneration of northern red oak. While treeshelters may improve regeneration success, they also may have positive and negative effects on seedling growth depending on their design and construction.

Results from this greenhouse and field study indicated that seedlings grown in clear or brown plastic shelters grew taller than unsheltered seedlings, but this height increase came at the expense of stem, leaf and root development and resulted in seedlings that could not support themselves after removal of the shelter. Seedling survival in brown and clear shelters was only improved by $5 \%$ and $20 \%$, respectively, over unsheltered seedlings. The reason(s) for high seedling mortality in the clear and brown shelters was unclear. Because the majority of the mortality occurred soon after planting, transplant shock of the bare-root seedlings may have been a factor. More research is needed to accurately determine the potential effects of increased air temperatures inside shelters on red oak survival and development.

The altered growth of red oak seedlings in treeshelters may have been the result of support and protection provided by the shelter, increased temperatures inside the shelters, or both. Shading did not appear to have a major positive influence on growth, although excessive shading in the greenhouse did cause greatly reduced seedling growth. Growth data from the greenhouse and field experiments suggested that height growth was not significantly reduced at $38 \%$ PAR but was reduced at $20 \%$ PAR. The light levels measured in the greenhouse are lower than would occur in a typical open clearcut but are representative of conditions that would exist in a thinned or shelterwood harvested stand (Johnson 1994). Thus, caution is necessary when using colored treeshelters in shaded conditions where light reductions could reach critical levels for seedling growth and where shade intolerant species are selected for planting.

Wire shelters appear to offer some advantages over other shelter designs. Seedling survival was improved by $40 \%$ over unsheltered seedlings and by $20 \%$ to $35 \%$ over clear and brown plastic shelters, respectively. Seedlings inside wire shelters were shorter but were structurally more sturdy. The differences in height growth between plastic and wire shelters may be unimportant over time. Dunn et al. (1994) and Burger et al. (1996) have suggested that height growth increases might be temporary. The cost of making woven wire shelters was similar to purchasing prefabricated plastic shelters. They required almost no maintenance during the 3-year field study, presumably because of less wind resistance. The brown and clear shelters required frequent maintenance because 
they fell over during windy periods or after large storms. In general, wire shelters protected seedlings from deer browsing without excessive maximum temperatures and protection from normal mechanical stress.

\section{LITERATURE CITED}

Bjorkman, O. 1981. Responses to different flux densities, pp 57-107. In Lange, O., P. Nobel, C. Osmond, and H. Zeigler (Eds.). Physiological Plant Ecology. I: Responses to the Physical Environment. Encycl. Plant Physiol., New Series. Vol. 12A. Springer-Verlag, New York, NY.

Burger, D.W., P. Suiha, and R. Harris. 1992. Treeshelter use in producing container-grown trees. HortScience 27(1):30-32.

Burger, D.W., G.W. Forister, and P.A. Kiehl, 1996. Height, caliper growth, and biomass response of ten shade tree species to treeshelters. J. Arboric. 22(4):161-166.

Demchik, M.C. 1998. The influence of soil nutrient conditions in northern red oak stands on litter decomposition, tree growth and tree mortality and the effect of soil nutrient amendments on tree growth and stump sprouting on Pennsylvania's Laurel Hill. Ph.D. thesis. Penn State University, University Park, PA. $159 \mathrm{pp}$.

Dunn, G.M., M.S. Cant, and M.R. Nester. 1994. Potential of two tree shelters to aid the early establishment and growth of three Australian tree species on the Darling Downs, south-east Queensland. Aust. For. 57(3):95-97.

Harris, R., A. Leiser, and W. Davis. 1976. Staking landscape trees. Univ. California Agr. Sci. Lflt. 2583.

Jaffe, M.J., and S. Forbes. 1993. Thigmomorphogenesis: The effect of mechanical perturbation on plants. Plant Regulat. 12:313-324.

Johnson, P.S. 1994. The silviculture of northern red oak. In Biology and Silviculture of Northern Red Oak in the North Central Region: A Synopsis. USDA Forest Service, North Central Forest Experiment Station. GTRNC-173. 68 pp.

Kjelgren, R. 1994. Growth and water relations of Kentucky coffee tree in protective shelters during establishment. HortScience 29(7):777-780.

Kjelgren, R., and L.A. Rupp. 1997. Establishment in treeshelters I: Shelters reduce growth, water use, and hardiness, but not drought avoidance. HortScience 32(7):1281-1283.

Kjelgren, R., D.T. Montague, and L.A. Rupp. 1997. Establishment in treeshelters II: Effect of shelter color on gas exchange and hardiness. HortScience 32(7): 1284-1287.

Kolb, T.E., K.C. Steiner, L.H. McCormick, and T.W. Bowersox. 1990. Growth response of northern red-oak and yellow-poplar seedlings to light, soil moisture and nutrients in relation to ecological strategy. For. Ecol. Manage. 38:65-78.

Kozlowski, T.T. 1979. Tree growth and environmental stresses. University of Washington Press, Seattle, WA. $37 \mathrm{pp}$.

Lantagne, D.O., C.W. Ramm, and D.I. Dickmann. 1990. Treeshelters increase heights of planted oaks in a Michigan clearcut. North. J. Appl. For. 7(1):24-26.

Loach, K. 1967. Shade tolerance in tree seedlings. New Phytol. 66:607-621.

Loach, K. 1970. Shade tolerance in tree seedlings II. Growth analysis of plants raised under artificial shade. New Phytol. 69:273-286.

Lynch, J.A., K.S. Horner, and J.W. Grimm. 1996. Atmospheric deposition: Spatial and temporal variations in Pennsylvania-1995. Prepared for the Pennsylvania Department of Environmental Protection. Penn State University, Environmental Resources Research Institute Report ER9607. 275 pp.

Lynch, J.A., K.S. Horner, and J.W. Grimm. 1997. Atmospheric deposition: Spatial and temporal variations in Pennsylvania--1996. Prepared for the Pennsylvania Department of Environmental Protection. Penn State University, Environmental Resources Research Institute Report ER9709. 326 pp.

Lynch, J.A., J.W. Grimm, and K.S. Horner. 1998. Atmospheric deposition: Spatial and temporal variations in Pennsylvania-1997. Prepared for the Pennsylvania Department of Environmental Protection. Penn State University, Environmental Resources Research Institute Report ER9811. 130 pp.

Mayhead, G.J., and T.A.R. Jenkins. 1992. Growth of young sitka spruce (Picea sitchensis (Bong. Carr.) and the effect of simulated browsing, staking and treeshelters. Forestry 65(4):453-462.

Mayhead, G.J., and I.R. Boothman. 1997. The effect of treeshelter height on the early growth of sessile oak (Quercus petraea (Matt.) Liebl.). Forestry 70(2):151-155.

Mebrahtu, I., and J.W. Hanover. 1991. Leaf temperature effects on net photosynthesis, dark respiration, and photorespiration of seedlings of black locust families with contrasting growth rates. Can. J. For. Res. 21:1616-1621

Phares, R.E. 1971. Growth of red oak (Quercus rubra L.) seedlings in relation to light and nutrients. Ecology 52:669-672.

Pierson, E.A., R.N. Mack, and R.A. Black. 1990. The effect of shading on photosynthesis, growth and regrowth following defoliation for Bromus tectorum. Oecologia 84:534-543.

Potter, M.J. 1988. Treeshelters improve survival and increase growth rates. J. For. 86(8):39-41. 
Potter, M.J. 1991. Treeshelters. Forestry Commission Handbook No. 7. HMSO Publications, London, England. $48 \mathrm{pp}$.

Smith, H.C. 1993. Development of red oak seedlings using plastic shelters on hardwood sites in West Virginia. USDA Forest Service Research Paper NE-672. 7 pp.

Swistock, B.R., K.A. Mecum, and W.E. Sharpe. 1999. Summer temperatures inside ventilated and unventilated brown plastic treeshelters in Pennsylvania. North. J. Appl. For. 16(1):1-4

Tuley, G. 1981. Treeshelters, p 12. In Forestry Commission Report on Forest Research, Edinburgh, Scotland.

Tuley, G. 1985. The growth of young oak trees in shelters. Forestry 58(2): 181-195.

\section{School of Forest Resources}

and Environmental Resources Research Institute

The Pennsylvania State University

Land and Water Research Building

University Park, PA16802

Corresponding author:

William E. Sharpe

104 Land and Water Research Building

University Park, PA 16802

Résumé. Des serres et des champs de culture ont été utilisés pour mesurer la croissance et survie de semis de chêne rouge (Quercus rubra L.) cultivés sans abris par rapport à d'autres placés sous abris de type brun translucide, acrylique clair et souple fait de broches. Dans la serre, les semis placés sous les abris de plastique brun ou d'acrylique clair avaient un développement des tiges, des feuilles et des racines significativement réduits par rapport aux semis non abrités. Les semis sous les abris clairs étaient plus grands que ceux du groupe contrôle, mais aucun ne parvenait à se tenir debout de lui-même lorsque la protection était enlevée. La croissance réduite sous les abris de couleur brune a été attribuée à une baisse de $80 \%$ de la radiation photosynthétique active. Dans le champs, les semis de deux ans de chêne rouge placés dans des abris bruns ou clairs ont connu moins de mortalitê ( $55 \%$ et $40 \%$ respectivement) que les semis non abrités (60\%), mais la plupart étaient incapables de supporter d'eux-mêmes après le retrait des abris en raison de la croissance accrue en hauteur et du développement inadéquat de la tige. La moitié des semis dans les abris clairs ont subi une mortalité de leur nouvelle pousse au cours d'une saison de croissance anormalement hâtive et chaude. Les semis dans les abris de broches n'ont pas été attachés ou protégés contre les stress mécaniques (vent) et ont été exposés aux températures ambiantes. Les semis dans les abris de broche ont eu le plus faible taux de mortalité (20\%) et se tenaient debout d'eux-mèmes, mais ils étaient significativement plus courts que les semis placés dans les abris clairs ou bruns. Les abris avec broches s'avèrent prometteurs comme alternative aux abris plastifiés rigides pour la production de semis se supportant d'euxmêmes avec un taux de croissance similaire et de survie supérieur à des coûts similaires.

Zusammenfassung. Um das Wachstum und Überleben von Roteichensämlingen in braunen transluzenten, klaren und aus Draht-geflecht bestehenden Baumschutzhüllen zu messen, wurden Versuche im Freiland und im Gewächshaus unternommen und die Ergebnisse mit ungeschützt wachsenden Sämlingen verglichen. Im Gewächshaus hatten die Sämlinge in braunen Plastikhüllen und in klaren Akrylhüllen deutlich reduzierte Stamm- Blatt- und Wurzelentwicklungen im Vergleich zu den ungeschützten Sämlingen. Die Sämlinge in klaren Schutzhüllen wuchsen größer als die Kontrollpflanzen, aber keiner konnte sich selbst halten, nachdem die Hüllen entfernt wurden. Das reduzierte Wachstum in den braunen Hüllen wurde begleitet durch eine $80 \%$ Reduktion der photosynthetisch wirksamen Strahlung (PAR). In der Feldstudie hatten die zweijährigen Sämlinge in braunen und klaren Hüllen eine niedrigere Sterberate (55\% bzw. 40\%) als ungeschützte $(60 \%)$, aber die meisten waren nicht in der Lage, sich selbst nach Entfernen der Hüllen zu halten wegen des verstärkten Höhenwachstums und der unadäquaten Stammentwicklung. Die Hälfte der Sämlinge in den klaren Schutzhüllen zeigten während einer ungewöhnlich warmen und frühen Wachstumsperiode Absterbeerscheinungen an den jungen Trieben. Die Sämlinge in den drahtgewobenen Schutzhüllen waren nicht vor mechanischem Stress geschützt und den Temperaturen ausgesetzt. Die drahtumhüllten Sämlinge hatten die geringste Absterberate (20\%), konnten sich selbst halten, aber waren deutlich kürzer als die in den Plastikhüllen. Die Drahthüllen erwiesen sich als gute Alternative $\mathrm{zu}$ soliden Plastikhüllen, wenn starke Sämlinge mit entsprechendem Wachstum und größerer Überlebensrate gezogen werden sollen bei ähnlich liegenden Allgemeinkosten.

Resumen. Se utilizaron experimentos de campo y de invernadero para medir el crecimiento y supervivencia de brinzales de roble rojo del norte (Quercus rubra L.) dentro de protectores de plástico café traslúcido, acrílico claro, y tejido de alambre, comparados con brinzales no protegidos. En el invernadero, los brinzales que crecieron en protectores plástico café y acrílico claro tuvieron desarrollo significativamente reducido de tallo, hojas y raíz, comparados con los brinzales no protegidos. Los brinzales en protectores claros crecieron más altos que los de control, 
pero ninguno pudo sostenerse después de remover los protectores. El crecimiento reducido en los protectores cafés fue atribuido a una disminución del $80 \%$ en radiación fotosintética activa (PAR). En el estudio de campo, los brinzales de dos años que crecieron en protectores café y claros, experimentaron más baja mortalidad ( $55 \%$ y $40 \%$, respectivamente) que los no protegidos $(60 \%)$ pero no pudieron sostenerse a sí mismos después de la remoción de los protectores, debido al incremento en altura y al inadecuado desarrollo del tallo. La mitad de los brinzales dentro de los protectores claros experimentaron muerte regresiva del nuevo crecimiento durante un calentamiento inusual en la estación temprana de crecimiento. Los brinzales en los protectores de tela de alambre no estuvieron sostenidos o protegidos del estrés mecánico (viento) y fueron expuestos a las temperaturas ambientales. Los brinzales con protectores de alambre tuvieron la mortalidad más baja (20\%) y se sostuvieron a sí mismos, pero fueron significativamente más pequeños que los de los protectores café y claros. Los protectores de alambre prometen ser una alternativa a los protectores sólidos plásticos para producir brinzales, que se sostengan por sí mismos, con crecimiento comparable y mayor supervivencia a un costo similar. 